西宮祐輔, 小沼利光, 田坂 健, 千堂年昭*

岡山大学病院 薬剤部

\title{
Drug interaction
}

(24. drug-drug interactions in intensive care unit)

Yusuke Nishimiya, Toshimitsu Konuma, Ken Tasaka, Toshiaki Sendo*

Department of Pharmacy, Okayama University Hospital

\section{はじめに}

平成 20 年度診療報酬改定により八 イリスク薬等に関する薬学的管理の 評価等が改正され救命救急入院料等 を算定している患者に対して薬剤管 理を行う場合 430 点が算定可能とな った。これに伴い薬郕師が活躍でき るフィールドは ICU 等の重症病棟 にも拡大している.当院において ICUへの入室理由は約 8 割が周術 期管理のための入室であり, 院内急 変および 3 次救急による入室が残り を占めている。

ICU において患者の評価は，肺・ 呼吸器, 心臓, 循環器, 腎臓, 電解 質, 感染症, 消化管, 内分泌, 神経 系と全身の臓器についてアセスメン 卜を行い，それぞれの器官に起きた 問題に対してゴールを設定して治療 を行う．特に，適切な循環および呼 吸管理なしに全身状態の改善には繋 がらないため, 心臓・循環器といっ た全身の血行動態・組織酸素化に必 須である臓器のアセスメントが重要 である1).

ICUのようなクリティカルケア

平成 24 年 5 月受理

*テ700-8558 岡山市北区鹿田町 2-5-1

電話 : 086-235-7640

FAX : 086-235-7794

E-mail :sendou@md.okayama-u.ac.jp
の現場では, 患者の循環動態, 呼吸 状態, 腎機能, 肝機能, 感染状態は 刻々と変化する. その中で患者が人 工呼吸器による管理, 経皮的心肺補 助装置の装着, 持続血液濾過透析あ るいは血液透析の導入を行われるケ ースも少なくない。

また，患者が糖尿病，高血圧，肺 気腫，肺炎，心不全などといった基 礎疾患を有している場合, ICU 入室 後の治療以外にも必要に応じて基礎 治療も継続して行われる.クリティ カルケアの現場において, 薬剤師は 注射薬・内服薬の薬物相互作用や注 射薬の配合変化・投与経路 - 投与速 度および希釈濃度に関する知識, 薬 物血中濃度モニタリング (TDM) に 関する知識など，薬剤に関する幅広 い知識と, さらに刻々と変化する患 者状態を把握し適切な薬剤を提案で きる総合的な能力が必要とされる. それには輸液・飲水・尿量などによ る水分量の in/outバランス, 心電 図, 血液ガス検査值, 血液検査值, 細菌感受性試験の評価など薬剤以外 の分野も熟知する必要がある。

ICUで使用される薬郕は非常に 多岐にわたるため, 全ての薬物相互 作用について把握することは非常に 困難である。そこで，本編では ICU において薬剤管理を行う上で，特に 頻出の薬剤を中心に概説する。また,
本稿では触れていない抗凝固薬, 抗 不整脈薬, 感染症に対する薬剤など については他稿を参照していただき たい.

\section{ストレス潰瘍予防薬}

ICU 入室中の患者において，ス卜 レス潰瘍が元となる出血リスクは 1.5～10\%という報告がある2. ス卜 レス潰瘍は胃全体部に起こることが 多く, 潰瘍の深さは浅く滲出性の出 血を起こすものから粘膜下層にまで 広がり大量出血や穿孔を引き起こす ものもある.胃粘膜の障害は粘膜へ の血流低下・酸素供給低下が元とな り, 胃粘膜の脱落や胃粘膜への血流 低下による粘膜組織の再生遅延のた め引き起こされる.また,腸管蝡動の 低下が胃酸停滞を起こすことが示唆 され, 粘膜障害がさらに進行すると 消化管出血を伴うストレス潰瘍形成 へとつながると考えられている(ス トレス関連粘膜障害：SRMD ${ }^{1)}$ 。粘 膜障害の原因は循環不全の他にもあ り，48時間以上の人工呼吸管理で SRMD に関連する消化管出血の頻 度が増すこと, 高 $\mathrm{CO}_{2}$ 血症下の換気 では胃液からの酸排泄が高まり胃潰 瘍が生じやすくなることが報告され ている2).

SRMD の予防にはプロトンポン プ阻害薬 (PPI) と $\mathrm{H}_{2}$ 受容体拮抗薬 
$\left(\mathrm{H}_{2} \mathrm{RA}\right)$ が繁用される.PPIの代 表例としては, オメプラゾール・ラ ンソプラゾール・ラベプラゾール が， $\mathrm{H}_{2} \mathrm{RA}$ の代表例としてはファモ チジンが挙げられる. SRMD に関連 する消化管出血に対して, PPI は $\mathrm{H}_{2} \mathrm{RA}$ と比較して治癒率の有意性は わずかであり，費用対効果の面では $\mathrm{H}_{2} \mathrm{RA}$ の方が優れているという報告 もある2). PPI の代謝には主にCYP が関与しているため，アゾール系抗 真菌薬やジゴキシンとの相互作用に 注意が必要である。また，免疫抑制 剂が必須である移植症例ではしばし ばCYPを介した薬物相互作用が問 題となる．PPIの中ではラベプラゾ ールがシクロスポリン・タクロリム スとの相互作用が無く, 選択される ケースが多い. $\mathrm{H}_{2} \mathrm{RA}$ の代表例であ るファモチジンは腎排泄であるため 比較的薬物相互作用は少ないが，イ トラコナゾールの吸収低下を引き起 こすため併用注意薬剤である，PPI および $\mathrm{H}_{2} \mathrm{RA}$ の代表的な相互作用 について表 1 に示す.

\section{降圧薬}

心不全や高血圧緊急症など心疾 患, 脳血管疾患の症例を多く扱うク リティカルケアの現場では血管拡張 薬, 降圧薬はなくてはならない薬剤
である．循環作動薬などによって血 圧が維持され脳や腎臓などの主要臓 器の灌流が確保されたら, 心臓に対 する前負荷・後負荷を適正に保ち末 梢循環を改善させる必要がある。前 負荷を軽減する静脈側容量血管拡張 薬の代表例はニトログリセリンなど の硝酸薬，後負荷を軽減させる動脈 側抵抗血管拡張薬には $\alpha$ 遮断薬や七 ドララジン, $\mathrm{Ca}$ チャネル拮抗薬， $\beta$ 受容体遮断薬などがあり, 前ならび に後負荷をバランス良く拡張するも のにはニトロプルシドなどがあ る ${ }^{3)}$. 使用する薬哓は即効性があり 短時間作用型の薬剤が望ましく, 血 管外漏出など点滴トラブルを防ぐた め CV ライン（単独ラインあるいは $\mathrm{CV}$ メインラインの側管）から投与 される。繁用される薬剤には, Ca チ ヤネル拮抗薬としてニカルジピン, ジルチアゼム, 硝酸薬としてニトロ グリセリンが挙げられる。 $\beta$ 受容体 遮断薬は, 心房細動 - 心房粗動の改 善を目的としてランジオロール・エ スモロールが使用される，降圧目的 では経口でカルベジロールなどが用 いられるがクリティカルケアで使用 するケースは少ない.また, ATP 感 受性 Kチャネル開口作用と cGMP 産生増加作用のあるニコランジルを 使用するケースもある。
降圧薬の中でも Ca チャネル拮抗 薬は主にCYP3A4で代謝されるた め，併用する場合には CYP3A4の基 質となる薬剤との相互作用に注意が 必要である。特に移植症例では，シ クロスポリン・タクロリムスの代謝 遅延が起こり得るので, これら薬剤 の血中濃度推移のフォローや副作用 モニタリングを行うべきである。降 圧薬に関して代表的な薬物相互作用 を表 2 に示す。

\section{循環作動薬}

クリテイカルケアの現場ではショ ックや心不全などの循環不全のため に循環作動薬を取り扱う例は多い。 循環作動薬を使用するうえで注意し なければならないのは, 昇圧薬や強 心薬はその場をしのぐ薬㧩という点 である，循環不全から回復させるた めにはその原疾患を治療する，とい うことを念頭に置かなければならな い.

脳や腎臓などの重要臟器や細胞の 機能を維持するのに十分な血液循環 が得られない結果，発生する生体機 能の異常をショックという。生体機 能を維持するのに十分な全身血液循 環が速やかに得られなければ不可逆 な危機的状況に陥るため, 循環作動 薬は早急かつ確実な投与が求められ

表 1 PPI および $\mathrm{H}_{2} \mathrm{RA}$ の薬物相互作用

\begin{tabular}{|c|c|c|c|}
\hline 薬 剂 名 & 臨 床 的 意 義 & 主な代謝酵素 & $\begin{array}{c}\text { 代謝酵素以外が関連する主な相互作用 } \\
\text { (機序不明を含む) }\end{array}$ \\
\hline オメプラゾール & ストレス関連粘膜障害の予防 & $\begin{array}{l}\text { CYP2C19 } \\
\text { CYP3A4 }\end{array}$ & $\begin{array}{l}\text { タクロリムス水和物, ジゴキシン, メチルジゴキシ } \\
\text { ン, イトラコナ゙゙ール }\end{array}$ \\
\hline ランソプラゾール & ストレス関連粘膜障害の予防 & $\begin{array}{l}\text { CYP2C19 } \\
\text { CYP3A4 }\end{array}$ & $\begin{array}{l}\text { タクロリムス水和物, ジゴキシン, メチルジゴキシ } \\
\text { ン, イトラコナゾール, ジアゼパム, フェニトイン }\end{array}$ \\
\hline ラベプラゾール & $\begin{array}{l}\text { ストレス関連粘膜障害の予防 } \\
\text { (相互作用のため上記 } 2 \text { 剤が } \\
\text { 使用し難い場合) }\end{array}$ & $\begin{array}{l}\text { CYP2C19 } \\
\text { CYP3A4 }\end{array}$ & $\begin{array}{l}\text { ジゴキシン, メチルジゴキシン，イトラコナゾール， } \\
\text { 水酸化アルミニウムゲル・水酸化マグネシウム含有 } \\
\text { の制酸剤 }\end{array}$ \\
\hline ファモチジン & ストレス関連粘膜障害の予防 & 腎排泄 & イトラコナゾール \\
\hline
\end{tabular}

(文献 6～9 から抜粋, 改変) 
表 2 降圧薬の薬物相互作用

\begin{tabular}{|c|c|c|c|}
\hline $\begin{array}{c}\text { 薬 剂 名 } \\
\text { (投与速度の目安) }\end{array}$ & 臨 床 的 意 義 & 主な代謝酵素 & $\begin{array}{c}\text { 代謝酵素以外が関連する主な相互作用 } \\
\text { (機序不明を含む) }\end{array}$ \\
\hline $\begin{array}{c}\text { ニカルジピン } \\
(0.5 \sim 6 \mu \mathrm{g} / \mathrm{kg} / \mathrm{min})\end{array}$ & $\begin{array}{l}\text { 高血圧性緊急症, 周術期管理 } \\
\text { の血圧コントロール }\end{array}$ & CYP3A4 & $\begin{array}{l}\text { プロプラノロール, フェンタニル, ジゴキシン , ニト } \\
\text { ログリセリン }\end{array}$ \\
\hline $\begin{array}{c}\text { ジルチアゼム } \\
(5 \sim 15 \mu \mathrm{g} / \mathrm{kg} / \mathrm{min})\end{array}$ & $\begin{array}{l}\text { 高血圧性緊急症, 周術期管理 } \\
\text { の血圧コントロール }\end{array}$ & CYP3A4 & $\begin{array}{l}\text { 降圧剂, 硝酸剂等, 抗不整脈薬（アミオダロン塩酸塩 } \\
\text { など), ジギタリス製剤 }\end{array}$ \\
\hline $\begin{array}{c}\text { ニコランジル } \\
(0.8 \sim 3.3 \mu \mathrm{g} / \mathrm{kg} / \mathrm{min})\end{array}$ & $\begin{array}{l}\text { 不安定狭心症, 急性心不全(慢 } \\
\text { 性心不全の急性増悪期を含む) }\end{array}$ & CYP の関与なし & シルデナフィル, バルデナフィル, タダラフィル \\
\hline
\end{tabular}

（文献10～15から抜粋，改変）

る。そのため投与の際は, 血管漏出 などの点滴トラブルを防ぐため CV ラインから投与することが重要であ る、繁用される薬剤としてはアドレ ナリン，ノルアドレナリン，ドパミ ン, ドブタミン, バソプレシン, フ エニレフリン，ミルリノンなどが挙 げられる。アドレナリンはアナフィ ラキシーショックの第一選択薬であ る. $0.2 \sim 0.5 \mathrm{mg}$ を筋注し反応が悪け れば10〜15分おきに投与を重ね最大 量として $1 \mathrm{mg}$ まで投与を試みる。ま た心肺蘇生 (CPR) の際にも使用さ れるが，これは $\alpha$ アドレナリン受容 体刺激作用により末梢血管が収縮し 心肺蘇生 CPR 中の脳灌流圧と冠灌 流圧が増加するため蘇生率の改善が 期待できるためである ${ }^{3)}$ 。通常, 循 環動態の維持にはノルアドレナリン が使用されるケースが多い．敗血症 性ショック初期の昇圧目的でカテコ ラミンを使用する場合はノルアドレ
ナリン $0.05 \sim 0.2 \mu \mathrm{g} / \mathrm{kg} / \mathrm{min}$ かバソ プレシン $1.5 \sim 2$ 単位 $/ \mathrm{hr}$ の持続投 与が推奨されている. バソプレシン は非アドレナリン性末梢血管収縮薬 であり冠動脈と腎動脈を収縮させ， 脳灌流圧と冠灌流圧を上げる作用を 持つ.ドパミンは低用量では腎血流 量の増加作用を示し, 大量投与では 昇圧作用を有する。また，ドブタミ ンは昇圧作用が弱いが左心室末期圧 低下作用を有し，ドパミンと併用す ることで重症心不全, 心原性ショッ クに拈いて相乗効果が得られるとい われている。フェニレフリンは選択 的 $\alpha_{1}$ 受容体刺激薬で末梢静脈から 投与可能な昇圧薬であり，アドレナ リンやノルアドレナリンと比較して 心毒性が弱いという特性をもつ。 $\beta$ 受容体を介さない強心作用とバラン 久の良い血管拡張作用を有する PDE III 阻害薬 (ミルリノン) やアデ ニル酸シクラーゼ賦活薬は, 前・後
負荷の低下に伴う循環動態の変調を きたしにくい3).

ドパミン，ドブタミン，アドレナ リン，ノルアドレナリンは $\mathrm{MAO} や$ COMT で代謝を受け, フェニレフリ ンは MAOの他 ADH や ALDH で 代謝され, CYP 分子種による代謝を 受けない。そのためCYPを介した 薬物相互作用は無いが， $\alpha$ 遮断薬あ るいは $\beta$ 遮断薬を併用すると予期せ ぬ血管収縮／拡張が起こりうるため 注意を要する。ミルリノンも CYP による代謝を受けないが他のカテコ ールアミンとは併用注意である。バ ソプレシンには併用注意薬が該当し ない。循環作動薬に関する薬物相互 作用を表 3 に示す。

\section{鎮静薬}

鎮静を行うことは，患者の疾患自 体の痛み・苦しみに加え，侵襲を伴 う治療あるいは診断による痛み・苦 
表 3 循環作動薬の薬物相互作用

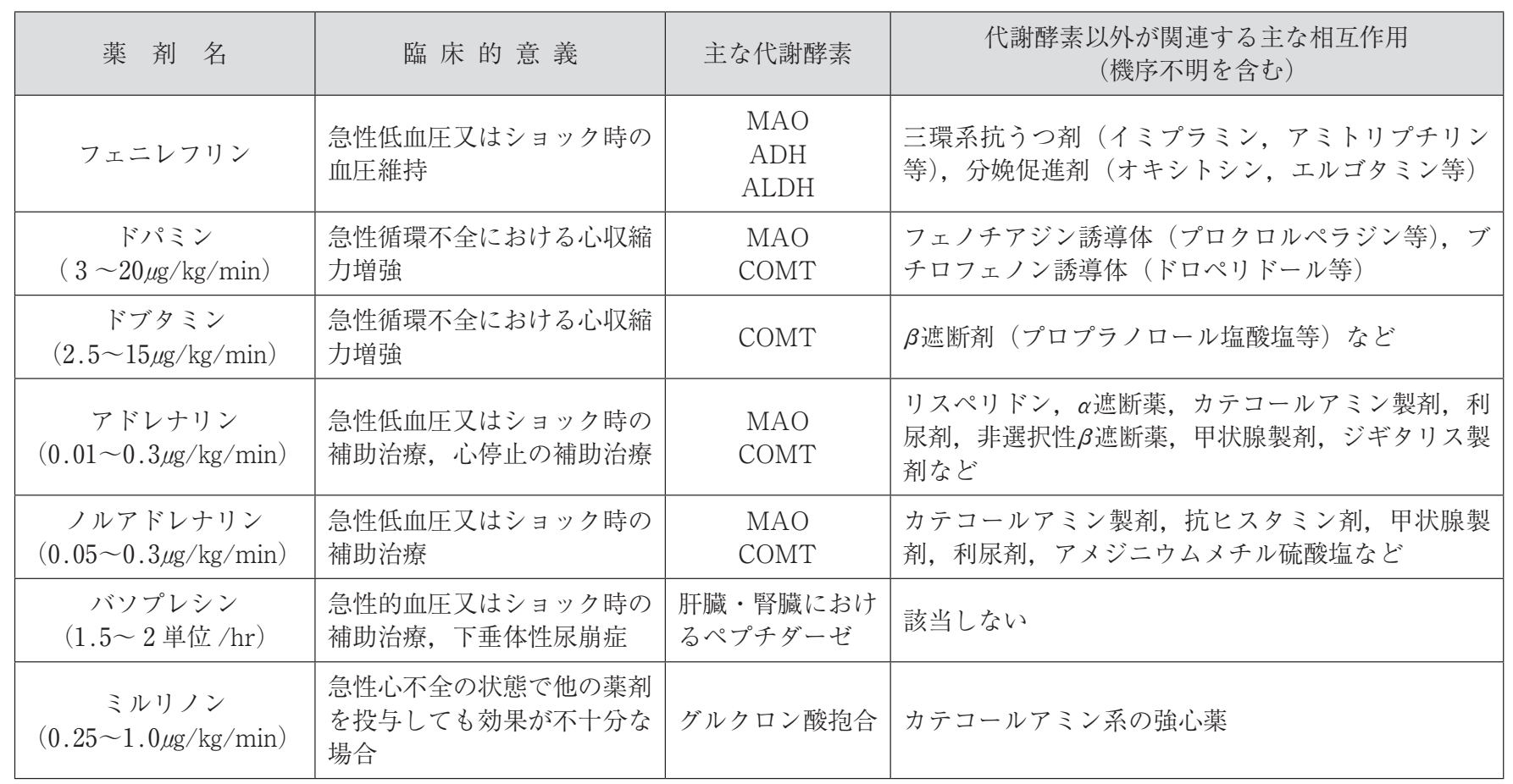

(文献16～22から抜粋，改変）

しみを軽減させる。また適切な鎮静 を行うことは, 血行動態・呼吸およ び精神面の安定からくる治療期間 · コスト面でのメリットをもたらし， 治療を快適に行うことを可能とす $ろ^{1)}$. 鎮静薬には人工呼吸管理中の 鎮静に使用されるミダゾラム・プロ ポフォール・デクスメデトミジンの ような鎮静薬が代表的である。これ らの他, クリティカルケアの現場で たびたび遭遇するせん妄に対して, ハロペリドール・トラゾドンなどの 薬剂も使用される。 せん妄は認知障 害を伴った意識障害と定義される状 態であり, 症状は数時間〜数日単位 の短期間出現し，1日のうちでも動 摇する。せん妄に対する薬剤は抗精 神病薬（ドパミン受容体アンタゴニ スト）のハロペリドールが第一選択 薬であり, 抗うつ薬であるトラゾド ンや非定型抗精神病薬であるクエチ アピン・オランザピン・リスペリド ンが使用されるケースもある。 BZ
系抗不安薬・睡眠薬は鎮静作用や筋 弛緩作用を持ち，認知機能を低下さ せるため基本的には用いない。ただ

しアルコール離脱せん妄にはジアゼ パム, ロラゼパム, クロルジアゼポ キシドを使用する ${ }^{4)}$.

プロポフォール・デクスメデトミ ジンといった鎮静薬は循環動態にも 影響し降圧作用を示すので, 降圧薬 を使用する際は過度の血圧低下に注 意が必要である，せん妄に対して繁 用されるトラゾドンは，ジギタリス 製剂およびフェニトインの血中濃度 を上昇させる（機序不明）という報 告があり併用注意である。八ロペリ ドールは抗コリン作用・抗ドパミン 作用を有するため, これらの作用を 持つ薬剤との併用に注意を要する。 また，ハロペリドール及びリスペリ ドンは,アドレナリン $\alpha$ 受容体遮断 作用を持ち，アドレナリンと併用す るとアドレナリン $\beta$ 受容体刺激作用 が有意となり血圧低下作用が増強さ
れるため併用禁忌である、鎮静薬に 関する薬物相互作用を表 4 に示す。

\section{鎮痛薬}

クリティカルケアでは，患者は疾 患自体の疼痛刺激だけでなく, 治療 や処置に伴う疼痛刺激にも晒されて いる。疼痛刺激は交感神経刺激とな り, 循環動態が不安定な場合は血行 動態が悪化する可能性があるが，こ れは適切な鎮痛を行うことで回避可 能である。痛みの評価方法には，視 覚アナログスケール (VAS), 数值 評価スケール (NRS), フェーススケ 一ルなどが使用される。モルヒネお よびフェンタニルが繁用される鎮痛 薬であるが，モルヒネは腎機能障害 のある場合では代謝物の蓄積を起こ すこと，ヒスタミン遊離作用による 血管拡張作用を有することから患者 の容態によっては使用し難い吕。ま た，局所麻酔薬のロピバカインをフ エンタニルと混合して硬膜外に持続 
表 4 鎮静薬の薬物相互作用

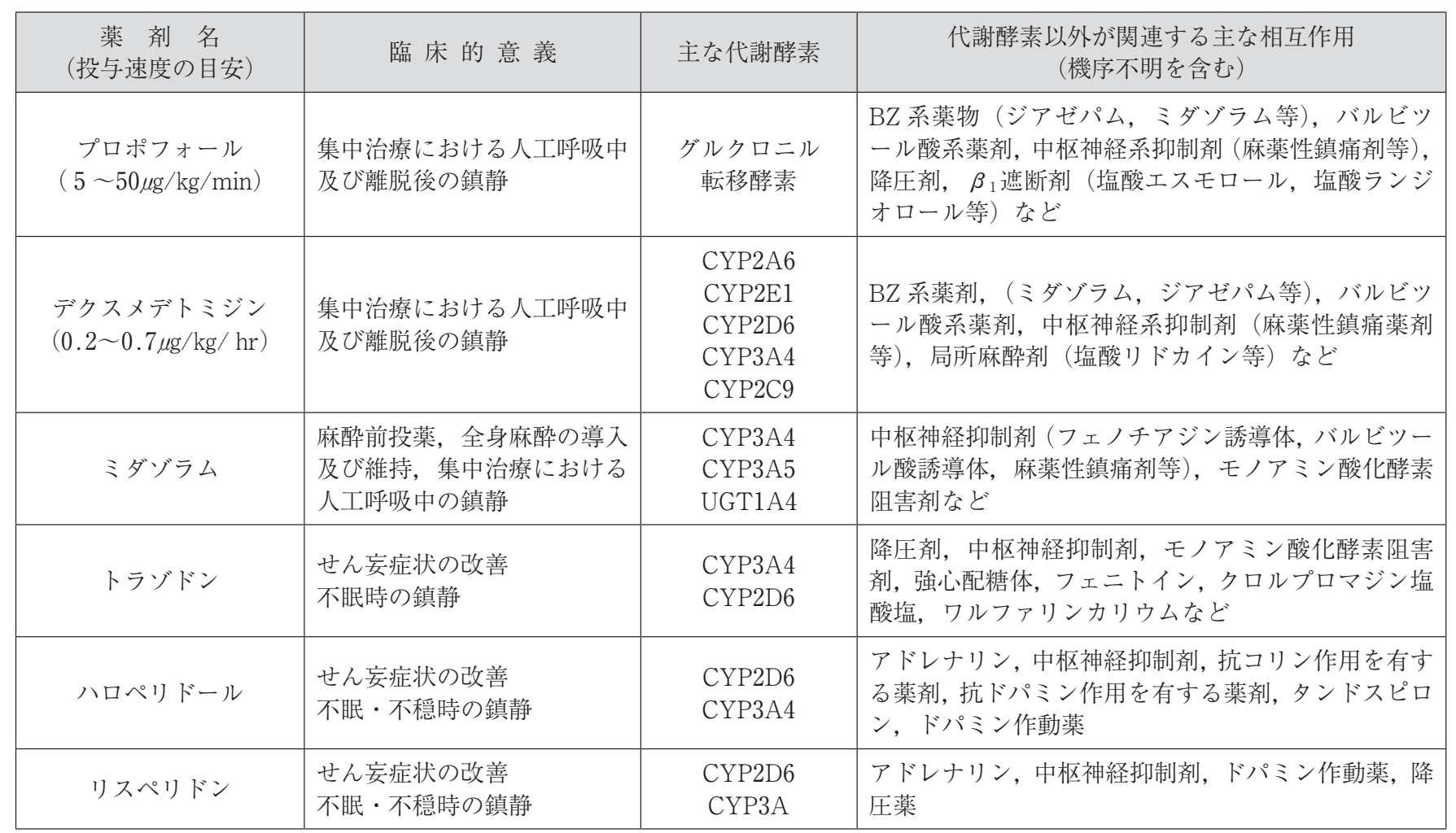

(文献23 28から抜粋, 改変)

投与されるケースもある。モルヒネ およびフェンタニルは呼吸抑制作 用・腸管蠕動低下作用があるため, 中枢神経抑制作用を持つ薬剂と併用 すると抑制作用増強されるため併用 注意である。また，ロピバカインは アミオダロン等のクラス III抗不整脈 薬と併用注意である(機序不明). 鎮 痛薬に関する相互作用を表 5 に示す。

\section{利尿薬}

循環動態の変調に伴い体内の水分 が血管内に移動すると, 循環血漿量 が増加し心不全, 肺水腫などの症状 を来す，そのため，利尿薬によって 血管内に貯留した余分な水分を除去 する。ここで重要な点は, 利尿薬が 充分に奏効するためには循環動態が 安定し腎血流量が保たれていなけれ ばならないことである ${ }^{5)}$ 。心機能低 下例ではカテコールアミンにて循環
動態を補正しなければ利尿を得られ ない場合がある，日本において一般 的に使用される利尿薬はループ利尿 薬, サイアザイド系利尿薬, $\mathrm{K}$ 保持 性利尿薬である。利尿薬の継続使用 により, 電解質異常（低 $\mathrm{Na}$ 血症, 低 $\mathrm{K}$ 血症, 低 $\mathrm{Mg}$ 血症）や体液量減 少によるレニン・アンジオテンシ ン・アルドステロン系（RAAS）の 活性化を引き起こす可能性があり注 意が必要である。

クリティカルケアの現場ではフロ セミドが最も使用されている。フコ セミドは主に腎臓から排出されるた め, 腎排泄の他の薬剂と併用すると それぞれの薬剤の排泄が阻害される ことがある。また，体内の水分量の 減少に伴い $\mathrm{Na} \cdot \mathrm{K}$ 等の電解質濃度 に影響を及ぼすためジギタリス製 剂, 糖尿病薬との併用に注意が必要 である。さらに，尿細管での $\mathrm{Na} の$
再吸収の増加に伴いアミノグリコシ ド系抗生剂の再吸収も増加するため 腎毒性・第 8 脳神経障害が増強する おそれがある。K保持利尿薬のスピ ロノラクトンはフロセミド同様繁用 されているが，高 $\mathrm{K}$ 血症誘発の可能 性から ACE 阻害薬やアンジオテン シン II 受容体拮抗薬と, 電解質濃度 に影響を及ぼすためジギタリス製郕 と併用注意である。また，スピロノ ラクトンはタクロリムスと併用禁忌 であることにも注意が必要である。 これらの他， $\alpha$ 型ヒト心房性ナトリ ウム利尿ポリペプチドのカルペリチ ドは，血管拡張作用が主体であるが 利尿目的にも使用される。このカル ペリチドは多剤と比較して薬物相互 作用が非常に少ないという特徵を持 つ. 利尿薬に関する薬物相互作用を 表 6 に示す。 
表 5 鎮痛薬の薬物相互作用

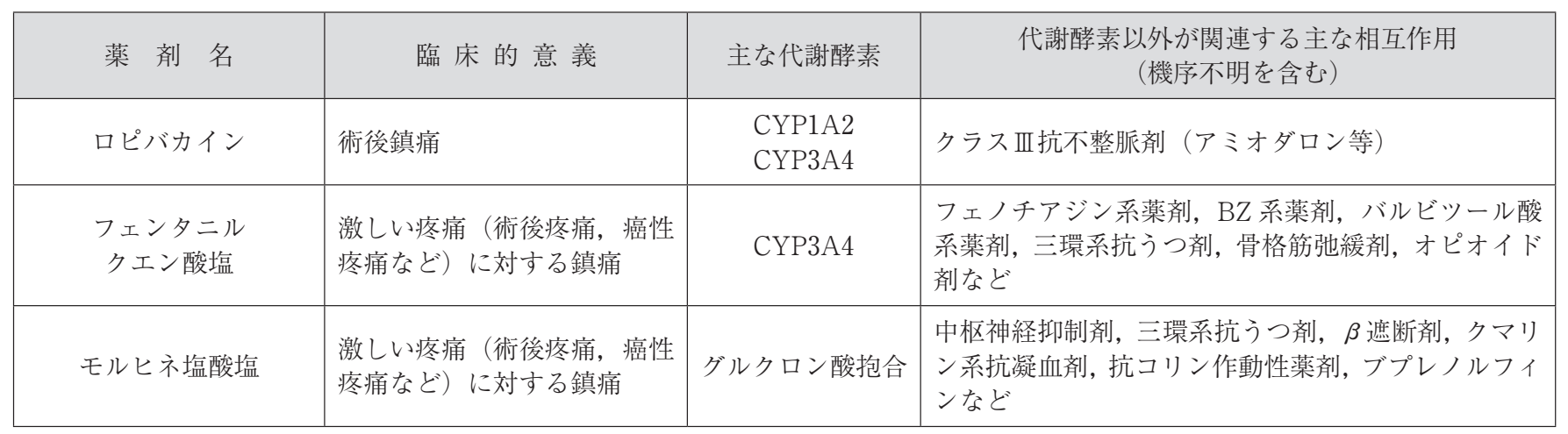

(文献29～31方ら抜粋, 改変)

表 6 利尿薬の薬物相互作用

\begin{tabular}{|c|c|c|c|}
\hline 薬 剂 名 & 臨 床 的 意 義 & 主な代謝酵素 & $\begin{array}{c}\text { 代謝酵素以外が関連する主な相互作用 } \\
\text { (機序不明を含む) }\end{array}$ \\
\hline フロセミド & $\begin{array}{l}\text { 過剰水分の排泄 } \\
\text { うっ血性心不全, 腎性浮腫, } \\
\text { 肝性浮腫, 脳浮腫などの改善 }\end{array}$ & $\begin{array}{l}\text { 未変化体の排泄 } \\
\text { グルクロン酸抱合 }\end{array}$ & $\begin{array}{l}\text { シクロスポリン, カテコールアミン, ACE 阻害薬, } \\
\mathrm{A}-\mathrm{II} \text { 受容体拮抗薬, ジギタリス製剤, 糖尿病薬など }\end{array}$ \\
\hline スピロノラクトン & $\begin{array}{l}\text { 過㮃水分の排泄 } \\
\text { うっ血性心不全, 腎性浮腫, } \\
\text { 肝性浮腫, 特発性浮腫などの } \\
\text { 改善 }\end{array}$ & グルクロン酸抱合 & 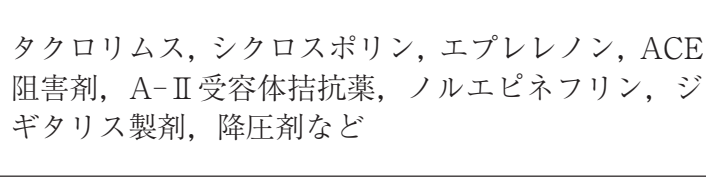 \\
\hline $\begin{array}{c}\text { カルペリチド } \\
(0.025 \sim 0.2 \mu \mathrm{g} / \mathrm{kg} / \mathrm{min})\end{array}$ & $\begin{array}{l}\text { 利尿, 急性心不全時の循環の } \\
\text { 補助（慢性心不全の急性増悪 } \\
\text { 期を含む） }\end{array}$ & $\begin{array}{c}\text { 腎臓・肝茞 } \\
\text { CYP の関与なし }\end{array}$ & フロセミド, PDE5 阻害薬 \\
\hline
\end{tabular}

（文献32～34から抜粋，改変）

\section{おわりに}

本稿で取り上げた薬剤は，クリテ イカルケアの現場で使用される薬剤 のうちのほんの一握りでしかない。 薬剂師は, 患者個々の病態にあわせ た輸液の選択, 抗 MRSA 薬の TDM による処方提案, 各感染症に適した 抗菌薬の選択, TPN 管理下の患者に おける栄養評価などに早期から参画 し, 不必要な薬物治療のために治療 期間が延長されるという事態が起こ らぬよう努めなければならない。

\section{文献}

1) 大野博司：ICU/CCU の薬の考え方, 使い方, 中外医学社, 東京 (2011) pp $1-11,15-46,57-67$.
2 ) 森 茂生, 田橋賢也, 岡崎和一: 久卜 レス潰瘍：ER・ICUでの薬の使い方 Q \& A ープロの実践と秘訣に学ぶ - 2011-' 12 (救急・集中治療 23 巻 $1 \cdot 2$ 号), 岡元和文編, 総合医学社, 東京 (2011) pp 239-246.

3 ) 岡元和文, 古川 誠, 守谷 俊, 丹正 勝久, 田中啓治, 中田 淳, 山本 剛： 心肺蘇生/急性心不全/心原性ショッ ク：ER・ICU での薬の使い方 Q \& A ープロの実践と秘訣に学ぶー 201112 (救急 - 集中治療 23 巻 $1 \cdot 2$ 号), 岡元和文編, 総合医学社, 東京 (2011) pp 1-21.

4) 浦島 創, 西村良二：せん妄症状： $\mathrm{ER} \cdot \mathrm{ICU}$ での薬の使い方 Q \& A プロの実践と秘訣に学ぶー2011-'12 (救急・集中治療 23 巻 $1 \cdot 2$ 号), 岡 元和文編，総合医学社，東京 (2011) pp 354-361.
5 ）澤野 誠, 間藤 卓, 稲角麻衣, 岩田 健太郎：全身管理：救急医療パーフ エクトマニュアル改訂版, 森脇龍太 郎，舆水健治編，羊土社，東京 (2009) pp 256-280.

6 ）オメプラール®注用20医薬品インタビ ユーフォーム (第11版), アストラゼ ネ力株式会社，大阪（2011）。

7 ）タケプロン®静注用 $30 \mathrm{mg}$ 医薬品インタ ビューフォーム (第 4 版), 武田薬品 工業株式会社，大阪 (2011).

8 ）パリエット®錠 $10 \mathrm{mg}$ 医薬品インタビュ ーフォーム (第16版)，エーザイ株式 会社，東京 (2012).

9 ) ガスター ${ }^{\circledR}$ 注射液 $20 \mathrm{mg}$ 医薬品インタビ ユーフォーム (第 9 版), アステラス 製薬株式会社，東京 (2012).

10）二カルピン®注射液 $10 \mathrm{mg}$ 医薬品インタ ビューフォーム (第 6 版)，沢井製薬 株式会社，大阪（2011）. 
11）ヘルベッサー ${ }^{\circledR}$ 注射用 250 医薬品イン タビューフォーム (第 8 版), 田辺三 菱製薬株式会社, 大阪 (2009).

12) ミオコール ${ }^{\circledR}$ 点滴静注 $25 \mathrm{mg}$ 医薬品イン タビューフォーム (第 7 版), トーア エイヨー株式会社, 東京 (2011).

13）シグマート ${ }^{\circledR}$ 注 $12 \mathrm{mg}$ 医薬品インタビュ ーフォーム (第 7 版), 中外製薬株式 会社, 東京 (2010).

14）ブレビブロック ${ }^{\circledR}$ 注 $100 \mathrm{mg}$ 医薬品イン タビューフォーム (第 4 版), 丸石製 薬株式会社, 大阪 (2011).

15）注射用オノアクト ${ }^{\circledR} 50$ 医薬品インタビ ユーフォーム (第 6 版), 小野薬品工 業株式会社, 大阪 (2010).

16）イノバン®注 $100 \mathrm{mg}$ 医薬品インタビュ ーフォーム (第 7 版), 協和発酵キリ ン株式会社, 東京 (2010).

17）ドブトレックス ${ }^{\circledR} キ ッ ト$ 点滴静注用 $600 \mathrm{mg}$ 医薬品インタビューフォーム

(第 5 版), 塩野義製薬株式会社, 大 阪 (2009).

18）ボスミン ${ }^{\circledR}$ 注 $1 \mathrm{mg}$ 医薬品インタビュー フォーム (第10版), 第一三共株式会 社, 東京 (2011).
19）ノルアドリナリン ${ }^{\circledR}$ 注 $1 \mathrm{mg}$ 医薬品イン タビューフォーム (第 6 版), 第一三 共株式会社, 東京 (2011).

20）ピトレシン 注射液20医薬品インタビ ユーフォーム (第 5 版), 第一三共株 式会社, 東京 (2011).

21）ネオシネジンコーワ注医薬品インタ ビューフォーム (第 3 版), 興和創薬 株式会社, 東京 (2009).

22) ミルリーラ ${ }^{\circledR}$ 注射液 $10 \mathrm{mg}$ 医薬品インタ ビューフォーム (第 8 版), アステラ 又製薬株式会社, 東京 (2012).

23） $1 \%$ \%゙ィプリバン®注医薬品インタビ ューフォーム (第13版), アストラゼ ネカ株式会社, 大阪 (2009).

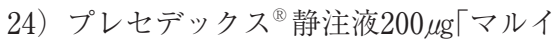
シ」医薬品インタビューフォーム（第 4 版), 丸石製薬株式会社, 大阪 (2010).

25）セレネース ${ }^{\circledR}$ 注 $5 \mathrm{mg}$ 医薬品インタビュ ーフォーム (第20版), 大日本住友製 薬株式会社, 大阪 (2012).

26）レスリン 錠 $25 \mathrm{mg}$ 医薬品インタビュー フォーム (第 7 版), MSD 株式会社, 東京 (2011).

27）リスパダール ${ }^{\circledR}$ 内溶液医薬品インタビ
ユーフォーム (第10版), ヤンセンフ アーマ株式会社, 東京 (2009).

28）ドルミカム ${ }^{\circledR}$ 注射液 $10 \mathrm{mg}$ 医薬品インタ ビューフォーム (第12版), アステラ 又製薬株式会社，東京 (2010).

29）フェンタニル注射液「ヤンセン」医薬 品添付文書 (第 2 版), ヤンセンファ 一マ株式会社, 東京 (2010).

30）モルヒネ塩酸塩注射液「夕ケダ」医薬 品添付文書 (第 8 版), 武田薬品工業 株式会社，大阪 (2009).

31）アナペイン ${ }^{\circledR}$ 注医薬品インタビューフ オーム (第 8 版), アストラゼネカ株 式会社, 大阪 (2011).

32）ラシックス ${ }^{\circledR}$ 注 $20 \mathrm{mg}$ 医薬品インタビュ ーフォーム (第 3 版), サノフィ・ア ベンティス株式会社, 東京 (2012).

33）アルダクトン ${ }^{\circledR} \mathrm{A}$ 錠 $25 \mathrm{mg}$ 医薬品インタ ビューフォーム (第 5 版), ファイザ 一株式会社, 東京 (2011).

34）ハンプ注射用 1000 医薬品インタビュ ーフォーム (第 7 版)，第一三共株式 会社, 東京 (2010). 